\title{
Pathophysiology of mesenteric ischemia/reperfusion: a review ${ }^{1}$
}

\author{
Fisiopatologia da isquemia e reperfusão mesentérica: revisão
}

\author{
Nereide Freire Cerqueira ${ }^{2}$, Carlos Alberto Hussni ${ }^{3}$, Winston Bonetti Yoshida ${ }^{4}$ \\ 1. Article from Faculty of Veterinary Medicine and Animal Science. UNESP - São Paulo State University. Botucatu. \\ 2. Doctor of Veterinary Medicine, School of Veterinary Medicine and Animal Science. UNESP - São Paulo State University. Botucatu. \\ 3. Associate Professor, Department of Veterinary Surgery and Anesthesiology. UNESP - São Paulo State University, Faculty of Veterinary \\ Medicine and animal Science. \\ 4. Associate Professor, Department of Surgery and Orthopedics. School of Medicine. UNESP - São Paulo State University. Botucatu.
}

\begin{abstract}
Pathophysiology of mesenteric ischemia/reperfusion: a review

During ischemia, the cell structures are progressively damaged, but restoration of the blood flow, paradoxically, intensifies the lesions caused by the ischemia. The mechanisms of ischemia injury and reperfusion (I/R) have not been completely defined and many studies have been realized in an attempt to find an ideal therapy for mesenteric I/R. The occlusion and reperfusion of the splanchnic arteries provokes local and systemic alterations principally derived from the release of cytotoxic substances and the interaction between neutrophils and endothelial cells. Substances involved in the process are discussed in the present review, like oxygen-derived free radicals, nitric oxide, transcription factors, complement system, serotonin and pancreatic proteases. The mechanisms of apoptosis, alterations in other organs, therapeutic and evaluation methods are also discussed.
\end{abstract}

Key words: Ischemia. Reperfusion. Mesenteric vascular occlusion. Reperfusion injury.

\section{RESUMO}

Fisiopatologia da isquemia e reperfusão mesentérica: revisão

Durante a isquemia, as estruturas celulares são progressivamente lesadas, mas a restauração do fluxo sanguíneo, paradoxalmente, pode agravar o dano celular isquêmico. O mecanismo das lesões de isquemia e reperfusão (I/R) ainda não foram completamente definidos e muitos estudos têm sido realizados na tentativa de encontrar uma terapia ideal para I/R mesentérica. A oclusão e a reperfusão das artérias esplâncnicas provocam alteracões locais e sistêmicas derivadas principalmente da liberação de substâncias citotóxicas e da interação entre neutrófilos e células endoteliais. As substâncias envolvidas no processo, como radicais livres derivados do oxigênio, óxido nítrico, fatores de transcrição, sistema complemento, serotonina e proteases pancreáticas, são discutidas na presente revisão. Os mecanismos de apoptose, repercussão sistêmica, terapêutica e métodos de avaliação também são discutidos.

Descritores: Isquemia. Reperfusão. Oclusão vascular mesentérica. Lesão de reperfusão.

The ischemia and reperfusion (I/R) syndrome performs a fundamental role in the pathophysiology of several clinicalsurgical conditions and may be caused by intestinal intussusception, acute mesenteric arterial occlusion, and hemodynamic shock ${ }^{1}$. Lesions caused by mesenteric I/R can also occur in transplants of the small intestine ${ }^{2}$.

Ischemia and reperfusion of the mesenteric blood vessels generally follows acute vascular insufficiency and the initial stages of multiple organ failure, conditions which are associated with high rates of morbidity and mortality ${ }^{3}$.

\section{Intestinal ischemia}

Intestinal ischemia is generally the result of arterial occlusion by thrombi or embolisms and, more frequently, by non occlusive processes, like in situations of low mesenteric flow which occurs in cardiac insufficiency, sepsis, the administration of alpha-adrenergic agents or digitalics ${ }^{4,5}$. The arteries most compromised by obstruction are the celiac trunk (or celiac artery), superior mesenteric (or cranial) artery (SMA) and inferior mesenteric (or caudal) artery $^{6}$. However, the sources of the collateral flow between the mesenteric blood vessels themselves or with adjacent circulation are numerous ${ }^{7}$ and may compensate the blood flow to the tissues.

Although less frequently found, the repercussions of mesenteric vein occlusion can be just as severe as arterial occlusion. Experiments on rats demonstrated that the occlusion of the cranial mesenteric vein provoked a smaller reduction in energetic metabolism than the occlusion of the cranial mesenteric artery, conversely, hemorrhage and tissue injury caused by venous occlusion elicited an irreversible tissue loss in the animals' intestines ${ }^{8}$. In humans, mesenteric venous thrombosis can result in hemorrhagic infarction with acute mesenteric ischemia and irreversible severe tissue lesions ${ }^{5}$. 
Arterial ischemia initiates alterations in tissues by blocking the oxygen supply, thus impeding aerobic energetic metabolism. This fact determines the depletion of intracellular levels of adenosine triphosphate (ATP) and disturbs cellular homeostasis ${ }^{9}$. During the ischemia process, aside from the inadequate supply of oxygen, with the consequent compromise of oxidative phosphorylation in the mitocondria, there is an accumulation of metabolites, which, directly or through mediators, can cause cellular injury ${ }^{10}$. With the evolution of ischemia, the continuous action of these elements results in progressive cellular alterations, culminating in necrosis. However, when the process which initiates ischemia is corrected before irreversible alterations can occur, oxygen return allows for the reestablishment of energetic metabolism, the removal of toxic products and the progressive return of normal cell functions ${ }^{9,11}$.

\section{Reperfusion}

Depending on the time and intensity of the ischemia, when oxygen is reintroduced to the tissues, tissue injury can be further exacerbated (oxygen paradox) ${ }^{12}$. Parks \& Granger $^{13}$ reported that tissue lesions produced during reperfusion were greater than those produced during ischemia, in mesenteric $\mathrm{I} / \mathrm{R}$ in felines. $\mathrm{I} / \mathrm{R}$ can provoke complex interactions between the endothelium and different cell types, leading to microvascular injury, cellular necrosis and/or apoptosis ${ }^{2}$. Occlusion and reperfusion of the splanchnic arteries precipitate circulatory shock, which, principally through an increase in vascular permeability, causes the activation and adhesion of polymorphonuclear neutrophils (PMNs), the release of proinflammatory substances and the formation of both nitrogen-derived and oxygen-derived free radicals (OFR) ${ }^{14,15}$. Injury provoked by splanchnic $\mathrm{I} / \mathrm{R}$ is characterized by intense infiltrated inflammations, found predominantly in the mucosae and submucosae, causing endothelial destruction ${ }^{15}$.

Ischemia and reperfusion of the small intestine provoke the rupture of the mucosa barrier, bacterial translocation and the activation of inflammatory responses ${ }^{16}$, as well as hydroeletrolytic and acid-alkaline equilibrium disturbances, which are manifested in distant organs ${ }^{17}$. Bacterial translocation is the passage of viable bacteria through the intestinal mucosa to mesenteric lymphatic nodes and other organs and tissues. The process of translocation involves the initial contact of the bacteria with the intestine wall, which alone can precipitate the production of cytocines and a subsequent inflammatory response. Once the bacteria penetrate the mucosa, they can be transported to distant organs by the circulation system. Hypoxia, followed by changes in the functioning of the intestine wall, promote a cycle of increased permeability leading to the release of toxic mediators, which results in accentuated permeability and the facilitation of bacterial translocation ${ }^{16}$. A study using marked bacteria showed that translocation in rats was more evident 24 hours after mesenteric reperfusion than after 30 minutes, indicating that time is a significant factor for translocation ${ }^{16}$. With the return of blood perfusion, the influx of calcium into the intracellular medium increases, which leads to an expressive increase in phospholipase $A_{2}$ activity. Arachidonic acid released by phospholipase $A_{2}$ is metabolized during reperfusion by the enzyme cycloxygenase (COX), generating prostaglandins (PG), thromboxane (TX) e prostacyclins ( $\mathrm{PGI}_{2}$ ), and by the enzyme lipoxygenase (LOX), which generates leukotrienes (LT) ${ }^{18}$. These substances can cause vasoconstriction (TXA , LTC $_{4}$, $\mathrm{LTD}_{4}, \mathrm{LTE}_{4}$ ), vasodilatation $\left(\mathrm{PGI}_{2}, \mathrm{PGE}_{1}, \mathrm{PGE}_{2}, \mathrm{PGD}_{2}\right)$, increased vascular permeability ( $\left.\mathrm{LTC}_{4}, \mathrm{LTD}_{4}, \mathrm{LTE}_{4}\right)$, can stimulate platelet aggregation and chemotaxia in the PMNs $\left(\mathrm{LTB}_{4}, \mathrm{HETE}\right)^{11}$. Aydemir-Koksoy et al. ${ }^{19}$ observed a reduction in the velocity and intensity in platelet aggregation after reperfusion in intestinal ischemia of rabbits.

\section{Reactive oxygen species (ROS)}

Another factor that induces intestinal injury after reperfusion is the generation of free radicals from oxygen molecules, derived from the electron transport chains of the mitocondria, xanthine-oxidase (XO) metabolism, endothelial cells, prostaglandins and activated neutrophils ${ }^{9}$.

Under normal conditions, the oxygen molecule $\left(\mathrm{O}_{2}\right)$ is submitted to a tetravalent reduction by the cytochrome system in the mitocondria, creating water $\left(\mathrm{H}_{2} \mathrm{O}\right)$. However, one to two percent of the $\mathrm{O}_{2}$ escapes this path and suffers a univalent reduction, generating oxygen-derived free radicals. In normal conditions, these radicals are neutralised by endogenous antioxidant enzymes, but during reperfusion an excessive concentration of free radicals occurs, eliciting a process called oxidative stress, with subsequent deleterious effects ${ }^{20}$. The ROS originate when $\mathrm{O}_{2}$ is reintroduced to the ischemic tissue during reperfusion. Free radicals are a class of chemicals, which have a single unpaired electron in their outer orbit. In this state, the free radicals are is extremely reactive and unstable, participating in reactions with organic and inorganic chemical substances, proteins, lipids, carbohydrates and, particularly, cell membranes and nucleic acids ${ }^{11}$. During the ischemic period, ATP is catabolized to produce hypoxanthine. Under physiological conditions hypoxanthine is oxidated to xanthine by way of xanthine dehydrogenase (XDH). During ischemia, an accumulation of intracellular calcium $\left(\mathrm{Ca}^{+2}\right)$ occurs and the conversion of $\mathrm{XDH}$ into xanthine oxidase (XO), where the degree of conversion of proportional to the time of ischemia. This reaction is quicker in intestinal tissue than in other tissues, which makes the measurement of XO a safe indicator for intestinal ischemia ${ }^{21}$. During reperfusion, the $\mathrm{O}_{2}$ is reintroduced into the tissue and reacts with hypoxanthine and $\mathrm{XO}$ to produce the superoxide anion $\left(\mathrm{O}_{2}\right)$, which is transformed into hydrogen peroxide $\left(\mathrm{H}_{2} \mathrm{O}_{2}\right)$ by the action of the enzyme superoxide dismutase (SOD) and through a reaction with catalase or glutationa peroxidase, $\mathrm{H}_{2} \mathrm{O}_{2}$ is further transformed into $\mathrm{H}_{2} \mathrm{O}^{20}$. In the presence of iron, the superoxide and $\mathrm{H}_{2} \mathrm{O}_{2}$ undergo the Haber-Weiss and Fenton reaction to form hydroxyl radicals $(\mathrm{OH})$, which are highly reactive and cytotoxic. Hydroxyl initiates lipidic peroxidation of the cell membrane components and the subsequent release of substances, which attract and promote the adherence of granulocytes to the microvascular endothelium. The attached granulocytes cause further injury to the endothelial cell 
through the release of superoxide and several proteases ${ }^{21}$. The superoxide ions react with nitric oxide (NO) to produce peroxynitrite, which then causes accentuated lipid peroxidation, proteic and DNA modifications resulting in cellular damage $\mathrm{e}^{22}$. All cellular components are susceptible to the action of ROS, though the membrane is one the most affected as a result of lipid peroxidation, which causes alterations in the structure and permeability of cellular membranes. The lipid-radical reactions release lipidic peroxides, which are in themselves free radicals, initiating the subsequent reduction of other fatty acids. Consequently there is a loss of selectivity in the ionic exchange and the release of the contents of the organelles, like the hydrolytic enzymes of the lysosomes and the formation of cytotoxic products culminating in cell death ${ }^{11,23}$. Besides precipitating lipid peroxidation, the ROS have the capacity to attract and activate neutrophils. The utilization of inflammatory cells is regulated by chemoattractors (C5a, IL-8, LTB 4 , PAF) generated during $\mathrm{I} / \mathrm{R}$, and also by the induction of various adhesion molecules on the surface of both inflammatory cells and venous endothelial cells. The adhesion molecules which regulate the leukocyte-endothelium interaction are the selectins, integrins b2 (CD11/CD18) and the immunoglobulins (ICAM-1, VCAM-1, PECAM-1) ${ }^{24}$.

The migration sequence of the leukocytes includes bordering the vessel wall, rolling along the endothelium and, finally, firm adhesion before transmigrating through the endothelium ${ }^{11,24}$. The active neutrophils, those which show adhesion molecules, after adhesion and migration through the endothelium cause local destruction through the release of more free radicals, proteolytic enzymes (collagenase, elastase, cathepsin G) and peroxidase. The capture of activated neutrophils in the lungs and other organs is an important step towards the development of multiple organ failure ${ }^{9}$. In normal rat intestine, ICAM-1 e VCAM-1 are constitutively expressed in the vascular endothelium. In response to I/R, they are superexpressed in the vascular endothelium cells, connective tissue, lamina propria and inflammatory cells. This superexpression of ICAM-1 and VCAM-1 accentuates the leukocyte adhesion and promotes their migration to the injured intestine during $\mathrm{I} / \mathrm{R}^{24}$. The microcirculation occlusion principally attributed to the mass adhesion of neutrophils in the capillaries is called the no-reflow phenomenon ${ }^{20}$.

Among the free radicals produced during I/R nitric oxide (NO) is also important. It is normally synthesized by L-arginine through NO synthase, which can have constitutive (cNOS) and induced (iNOS) isoforms ${ }^{25}$. The excess production of NO through induced NO synthase (iNOS) contributes to the pathophysiology of $\mathrm{I} / \mathrm{R}$ in the intestine $^{15,22}$. However, NO produced through constitutive NO synthase (cNOS) can be an important protective molecule for the small intestine at the onset of $\mathrm{I} / \mathrm{R}^{26}$. Nitric oxide presents beneficial vasodilatory effects in the microvascular system, through the relaxation of the smooth vascular muscle cells, but, paradoxically, could be involved in the production of cytotoxic radicals ${ }^{27}$. According to Sekhon et al. ${ }^{28} \mathrm{NO}$ is beneficial as a modulator or messenger, but during oxidative stress is potentially toxic. Naito et al. ${ }^{29}$ observed that inflammation induced by mesenteric reperfusion in rats resulted in oxidative and nitrosative stress, characterized by the high production of NO, by the increased expression of iNOS and by an excess expression of lipidic peroxides. Tissue ischemia and reperfusion activate families of protein kinases which converge to specific transcription factors [protein activator-1 (PA-1) and nuclear factor-kB (NF-kB)], which regulate the expression of proinflammatory genes. The resulting products include enzymes (iNOS, phospholipase $A_{2}$, cycloxygenase), cytocines (TNF-a, IL-1, IL-6) and adhesion molecules $(\mathrm{ICAM}-1)^{30}$. NF-kB is maintained in a latent form in the cytoplasm and, under certain conditions translocates to the nucleus, where it regulates the transcription ${ }^{22}$. According to Zou et al. ${ }^{31}$, NF-kB appears to perform an important function in the generation and resolution of intestinal $\mathrm{I} / \mathrm{R}$ lesions. NF-kB is activated by the intestine due to proinflammatory stimuli, including sepsis, cytocines and oxidative stress. The activation of NF-kB leads to the coordinated expression of many genes which codify proteins involved in mediator synthesis and in the amplification and maintenance of inflammatory response. Thus, NF-kB functions as a marker for antiinflammatory treatment ${ }^{31}$. The activation of the complement system can lead to the translocation of NF-kB and an increase in the transcription of iNOS. The complement system exerts a significant function in the lesion pathogenesis resulting from $\mathrm{I} / \mathrm{R}$ and its activation can also contribute to the increased production of superoxide anion not only through the utilization and activation of neutrophils, but also through a reduction in the levels of SOD after reperfusion ${ }^{22}$.

The depletion or inhibition of the complement could diminish many of the mediators of I/R injury. Complement component 5 (C5) measures the intestinal lesions through regulation of ICAM-1, TNF-a and IL- $1 \mathrm{a}^{22}$. Although it is clear that blocking the complement can protect tissues from reperfusion injury, the specific molecular mechanisms of injury induction at a cellular level are still under investigation. In gastrointestinal I/R, the complement induced iNOS expression of the intestinal epithelium of rats $^{22}$. The activation of neutrophils was also complementdependent during intestinal $\mathrm{I} / \mathrm{R}^{32}$. On the other hand, Fleming et al. ${ }^{33}$ showed that C5a provoked limited injury, after mesenteric I/R in mice, independent of the PMNs.

Additionally, mastocytes may be involved in exacerbating injury after the activation of the complement. Mastocytes, and the reactions induced by them, appear to contribute to the increase in mucosa permeability during reperfusion, but their function in pathological injury remains unknown ${ }^{32}$. Evidence suggests that besides PMNs and endothelial cells, other cells exert significant functions in the pathogenesis of postischemic reperfusion injury. The platelets are utilized by the postischemic microvasculature soon after the onset of reperfusion and, even though they are anuclear, still generate free radicals, release proinflammatory mediators like $\mathrm{TXA}_{2}$, leukotrienes, serotonin, platelet factor- 4 and PDGF and modulate leukocyte function. The accumulation of platelets in the postischemic microvasculature could contribute significantly to the manifestation of I/R lesions ${ }^{2,34}$.

Platelets, similar to leukocytes, roll and firmly adhere to the vascular endothelium during postischemic reperfusion. The cellular interactions between endothelial 
cells and platelets induced by $\mathrm{I} / \mathrm{R}$ are mediated through endothelial P-selectin, while platelet P-selectin promotes platelet-leukocyte interaction ${ }^{34}$. The interactions between these two cell types can provoke reciprocal activation, resulting in increased expression of the adhesion molecules, in the generation of superoxide and in the phagocytic activity of the leukocytes ${ }^{35}$.

Another factor involved in the lesions of intestinal I/R is serotonin (5-HT). Serotonin is a bioactive amine, which acts, in several physiological phenomena like neurotransmission, intestinal movement, platelet activation and vasoconstriction ${ }^{36}$. A study realized by Teramoto et al. ${ }^{36}$ showed an increase in the plasmatic levels of 5-HT after mesenteric $\mathrm{I} / \mathrm{R}$ in rats, probably due to an increase in the release of 5-HT by the injured intestine. According to the authors, 5-HT together with other bioactive substances could perform an important function in the pathogenesis of intestinal I/R. It has been demonstrated recently that pancreatic proteases are involved in the production of inflammatory mediators after intestinal I/R, such as trypsin and metalloproteinase-9 (MMP-9). MMP-9 is an endoprotease which has zinc in its active nucleus, and is involved in immune and inflammatory responses, including I/R of the myocardia, liver and pancreas ${ }^{37}$. Rosario et al. ${ }^{37}$ observed that intraluminal trypsin increased the inflammatory response, with an increase in neutrophil infiltration in the intestinal wall. Pancreatic trypsin promoted a rapid proteolytic activation of MMP-9, acting as a potential mechanism for injury. Growing evidence suggests that platelet aggregator factor (PAF) exerts an important function in the initiation and amplification of $\mathrm{I} / \mathrm{R}$ lesions $^{38}$. PAF is a lipidic mediator for inflammatory response and promotes mucosal apoptosis, induced by I/R in the small intestine. I/ $\mathrm{R}$ inhibits the activity of PAF-acetylhydrolase (PAF-AH), resulting in an increase of PAF activity. Activated PAF accentuates the expression of PECAM-1 and the secretion of IL-6 and inhibits the synthesis of IL-10, which exerts antiinflammatory functions during intestinal reperfusion ${ }^{38}$. The release of mitocondria cytochrome for cytosol occurs to activate caspase- 9 , which, in turn, increases apoptosis in the mucosa ${ }^{38}$. In the past, necrosis was considered to be the principal effect of ischemia on epithelial cells. More recent studies indicate that apoptosis is clearly a significant and, perhaps, the principal contributor to cellular death after I/R injury ${ }^{39}$. Contrary to cellular necrosis, apoptosis is an active process of genetically driven cellular self-destruction and is characterized by morphological changes, like cellular shrinkage while maintaining the organelles intact, chromatin condensation and the eventual fragmentation of the nucleus and the forming of "apoptotic bodies" by the cytoplasm ${ }^{40}$. The main executors of "programmed cell death" are the endoprotease cysteines called caspases ${ }^{41}$.

Several studies have evaluated apoptosis in intestinal I/R. Noda et al. (1998) ${ }^{40}$ report apoptosis in the jejunum and ileus, after SMA occlusion and reperfusion in rats. Apoptosis did not occur in the duodenum, as there was no reduction in the blood flow after SMA occlusion. The percentage of DNA fragmentation increased during ischemia and reached a maximum one hour after reperfusion. According to Wu et al. ${ }^{42}$ iNOS is related to increased apoptosis in the small-intestine mucosa of rats after I/R.
Apoptosis inhibitors in injured tissue can preserve functional and morphological integrity in organs submitted to $\mathrm{I} / \mathrm{R}^{43}$. Jacob et al. ${ }^{41}$ reported that glycine prevented the induction of apoptosis in a mesenteric I/R model in rats.

\section{Systemic repercussions}

Multiple organ failure is a frequent complication after intestinal I/R and involves organs like the liver ${ }^{44}$, heart ${ }^{45}$, kidneys ${ }^{46}$ and lungs ${ }^{47}$. Reactive chemical species initiate a sequence of events including the activation of neutrophils and the release of harmful substances like PAF and histamine. Activated neutrophils infiltrate through the intestinal epithelium and endothelial cells, causing mucosal and submucosal injury, with the consequent increase in vascular permeability. This increase in permeability results in translocation of enteric bacterial products. Besides this, the release of neutrophils, bacterial products and PAF lead to distant pathophysiological effects, including systemic hypertension ${ }^{48}$. According to Iglesias et al. ${ }^{49}$, acute pulmonary edema resulting from mesenteric $\mathrm{I} / \mathrm{R}$ is due to the increase of pulmonary microvascular permeability to fluids and proteins, as well as the increase in hydrostatic microvascular pressure. Horton and White ${ }^{45}$ demonstrated that one of the mechanisms that promotes cardiac dysfunction after intestinal $\mathrm{I} / \mathrm{R}$ in rats is the production of ROS and lipidic peroixdation in cardiac cell membranes. Hepatic injury induced by mesenteric I/R was diminished with the administration of ethanol, which may have inhibited the apoptosis of hepatocytes ${ }^{44}$.

\section{Therapeutics}

Several endogenous mechanisms exist to inhibit I/R lesions and many drugs have shown protective effects. These agents act through various pathways: elimination of free radicals; inhibition of free radicals production; neutrophilic inhibition; blocking phospholipase $\mathrm{A}_{2}$, cycloxygenase and lipoxygenase; platelet aggregation factor inhibition; production of blockers for chemotaxic agents and monoclonal antibodies to counter adhesion molecules. However, none of the treatments in isolation were effective in limiting oxidative damage $\mathrm{e}^{9,20}$.

The administration of allopurinol, a xanthine-oxidase inhibitor ${ }^{50}$ and the use of epidermal growth factor (EGF) ${ }^{3}$ offered protection after I/R in rat small-intestine. Ilhan et al. ${ }^{51}$ showed that the administration of allopurinol and monoclonal antibodies to counter adhesion molecule ICAM1 before mesenteric reperfusion diminished the lesions resulting from I/R in rats. Many other agents have been tested experimentally and have prevented or diminished mesenteric I/R injury during research. Hydrocortisone was capable of diminishing reperfusion lesions after venous ischemia in horse jejunum ${ }^{52}$. 21-aminosteroid, an agent with similar properties to corticosteroids, though without their undesired effects, was not capable of protecting horse jejunum after partial vascular occlusion followed by reperfusion ${ }^{53}$. Other strategies have been proposed to protect tissues from I/R injury, like hypothermia and ischemic or pharmacological preconditioning. Ischemic preconditioning is defined as a brief period of ischemia 
followed by reperfusion (isolated or in cycles) which precedes a prolonged period of ischemia ${ }^{54}$. Ischemic preconditioning diminished morphological lesions in rat intestine after $\mathrm{I} / \mathrm{R}^{55}$. Abrahão et al. ${ }^{54}$ found no histological differences when comparing fragments of rat intestine submitted to I/R with animals submitted to ischemic preconditioning, however, the biochemical dosage showed that preconditioning protected the intestine from I/R injury.

The protection mechanisms of hypothermia are multifactoral and have to be defined. A number of mechanisms have been proposed, including the reduction of $\mathrm{O}_{2}$ consumption, ATP depletion, neutrophil activation, lipidic peroxidation and the production of proinflammatory cytocines ${ }^{56}$. Hassoun et al ${ }^{56}$ observed that intestinal regional hypothermia applied during mesenteric ischemia reduced the proinflammatory responses induced by I/R, but showed no significant effect in microvascular barrier alterations during reperfusion in dogs. Attuwayb et al. ${ }^{57}$ demonstrated that hypothermia protected rat intestines from I/R injury and that, according to the authors, this protection was associated with diminished NF-kB activity and the induction of iNOS, as well as the expression of heme oxygenase-1 (HO-1). According to Stefanutti et $\mathrm{al}^{1}$, moderate hypothermia has beneficial effects on the heart, liver, intestine and lungs after mesenteric I/R. Moderate hypothermia, characterized by a rectal temperature between 30 and $33^{\circ} \mathrm{C}$, diminished the infiltration of neutrophils in rat lung after mesenteric I/ $\mathrm{R}^{47}$. Aldemir et $\mathrm{al}^{58}$, in an experimental study on rats, observed that the in vivo freezing of SMA and pretreatment with mannitol before reperfusion were beneficial in the prevention of intestinal I/R lesions.

\section{Evaluation}

Mesenteric I/R can be evaluated by the detection of various products resulting from injury, using laboratorial, histomorphological and anatomopathological methods. Mean arterial pressure in rats, after mesenteric I/R, was evaluated by means of catheters introduced in to the femoral or carotid artery ${ }^{14}$. Intestinal microvascular ${ }^{59}$ and cranial mesenteric arterial blood flow ${ }^{60}$, as well as cardiac frequency ${ }^{45,48}$ are parameters that have also been evaluated in experimental mesenteric I/R. The evaluation of hemogasometric parameters was performed by Kozar et al. ${ }^{61}$, who studied $\mathrm{pH}, \mathrm{PaO}_{2}, \mathrm{PaCO}_{2}, \mathrm{HCO}_{3}$ and base excess after intestinal I/R in rats. Iwanami et al. (1998) ${ }^{62}$ measured the intra-luminal $\mathrm{pH}$ in a mesenteric $\mathrm{I} / \mathrm{R}$ model in dogs and observed a correlation between a fall in intestinal $\mathrm{pH}$ and the degree of histological lesions observed after one hour of reperfusion. Lipidic peroxidation is frequently used to prove the involvement of free radicals in cell damage, through the detection of lipidic hydroperoxides and dienes found together ${ }^{63,64}$. Malondialdehid is one of the final products of lipidic peroxidation and several methods have been proposed for its determination. Such methods are based on MDA reaction to thiobarbituric acid, generating a chromophor which can be detected by spectrophotometry, fluorometry and, most specifically, by HPLC (highperformance liquid chromatography $)^{64}$. MDA can be dosed in both tissue and blood and its concentration is directly proportional to the cell damage caused by free radicals ${ }^{63}$.
Besides lipidic peroxidation, the measurement of proteic and DNA damage and of antioxidants has been performed to quantify ROS in vivo ${ }^{64}$. The detection of free radicals in biological systems is made difficult by their extremely low concentrations (in the order of $10^{-11} \mathrm{M}$ ) and by their high reaction velocity ${ }^{23}$. Direct detection of free radicals during $\mathrm{I} / \mathrm{R}$ can be realized by the electron paramagnetic resonance technique, salicylate hydroxylation and chemoilluminescence ${ }^{64}$. The methods most used for indirect free radicals verification and, consequently, oxidative lesions are spectrophotometry and chromatometry, which measure enzyme activity (SOD, catalase, GSH-Px and GSH-Rd) and/or the concentration of tripeptides (GSH, GSSG) and aldehydes (MDA). These measurements can be performed on tissue, blood and other fluids $^{23}$. Indirect detection of NO can be performed by chemiluminescence, oxyhemoglobin to methemoglobin conversion or the quantification of stable NO metabolites, like nitric and nitrate ${ }^{27}$. Other methods have been proposed. Hedge et al. ${ }^{65}$ evaluated the mesenteric viability and observed that the frequency and amplitude of intestinal electrical activity (basic electrical rhythms) were sensitive to ischemia and that they registered change before histological alterations occurred. Variation in the electrical activity of the small intestine during I/ $\mathrm{R}$ is a dynamic process, which reflects the metabolic state of the smooth muscle.

Sun et al.$^{66}$ observed that measurement of D-lactate in plasma could be an intestinal injury marker, monitoring the increase in permeability and endotoxemia after mesenteric I/R in rats. Günel et al. ${ }^{67}$ believe that an elevated level of Dlactate may be used as a parameter to identify patients with ischemia before laparotomy. The intestinal fatty acid bonding proteins (I-FABP) are small intracellular proteins which exist in the mucosa of the intestinal epithelial of many mammals and can be detected in the plasma and urine after cellular injury ${ }^{68}$.

\section{Conclusions}

Intestinal ischemia performs a fundamental role in the pathophysiology of several clinical-surgical conditions and reperfusion results in more severe tissue injury than with ischemia alone. The events which occur during I/R are complex and well studied, although, there still remain many doubts as to their pathophysiology and therapeutics, revealing the need for new research to obtain a more complete understanding and in the search for improved treatments.

\section{References}

1. Stefanutti G, Vejchapipat P, Williams SR, Pierro A, Eaton S. Heart energy metabolism after intestinal ischaemia and reperfusion. J Pediatr Surg. 2004;39:179-83.

2. Massberg S, Messmer K. The nature of ischemia/ reperfusion injury. Transplant Proc. 1998;30:4217-23.

3. Berlanga J, Prats P, Remirez D, Gonzalez R, Lopez-Saura P, Aguiar J, Ojeda M, Boyle JJ, Fitzgerald AJ, Playford RJ. Prophylactic use of epidermal growth factor reduces ischemia/reperfusion intestinal damage. Am J Pathol. 2002;161:373-9. 
4. Stoney RJ, Cunninghan CG. Acute mesenteric ischemia. Surgery. 1993;114:489-90.

5. McKinsey JF, Gewertz BL. Isquemia mesentérica aguda. In: Schwartz LB, Gewertz BL. Isquemia mesentérica. Rio de Janeiro: Interlivros; 1997. p.313-24.

6. Simi AC. Isquemia intestinal. In: Maffei FHA, Lastória S, Yoshida WB, Rollo HA. Doenças vasculares periféricas. 3ed. Rio de Janeiro: Medsi; 2002. p.1239-57.

7. Rosenblum JD, Boyle CM, Schwartz LB. Circulação mesentérica: anatomia e fisiologia. Rio de Janeiro: Interlivros; 1997. p.295-311.

8. Kimura M, Kataoka M, Kuwabara Y, Sato A, Sugiura M, Fujii Y. Real-time energy metabolism of intestine during arterial versus venous occlusion in the rat. J Gastroenterol. 2003;38:849-53.

9. Grace PA. Ischaemia-reperfusion injury. Br J Surg. 1994;81:637-47.

10. Granger DN, Hollwarth ME, Parks DA. Ischemiareperfusion injury: role of oxygen-derived free radicals. Acta Physiol Scand Suppl. 1986;548:47-63.

11. Cotran RS, Kumar V, Robbins SL. Lesão e morte celular. In: __ Robbins: patologia estrutural e funcional. 5ed. Rio de Janeiro: Guanabara Koogan; 1996. p.1-30.

12. McCord JM. Oxygen-derived free radicals in postischemic tissue injury. N Engl J Med. 1985;312:159-63.

13. Parks DA, Granger DN. Contributions of ischemia and reperfusion to mucosal lesion formation. Am J Physiol. 1986;250:G749-53.

14. Macarengo RSS, Takahagi RU, Bardella LC, Sequeira JL, Yoshida WB. Estudo da ação do extrato de Gingko biloba e amido hidroxietílico hipertônico na atenuação de alterações decorrentes de isquemia e reperfusão de órgãos esplâncnicos em ratos. Acta Cir Bras. 2001;16:139-45.

15. Cuzzocrea S, Chatterjee P, Mazzon E, Dugo L, De Sarro A, Van de Loo FAJ, CaputiAP, Thiemermann C. Role of induced nitric oxide in the initiation of the inflammatory response after postischemic injury. Shock. 2002;18:169-76.

16. João AS, Alencar SSS, Medeiros AC, Diniz SOF, Cardoso VN, Brandt CT. Translocation of 99mTc labelled bacteria after intestinal ischemia and reperfusion. Acta Cir Bras. [serial online] v.19 2004. Disponível em: http://www.scielo.br/acb [also in CD-ROM]. Acesso em: 15 ago 2004.

17. Turnage RH, Guice KS, Oldham KT. Endotoxemia and remote organ injury following intestinal reperfusion. J Surg Res. 1994;56:571-8.

18. Cuzzocrea S, Rossi A, Serraino I, Di Paola R, Dugo L, Genovese T, Caputi AP, Sautebin L. 5-Lipoxygenase knockout mice exhibit a resistance to splanchnic artery occlusion shock. Shock. 2003;20:230-6.

19. Aydemir-Koksoy A, Koksoy C, Kuzu MA, Demirpence E, Cinel I, Kesenci M, Yavuzer S. Intestinal ischemiareperfusion leads to platelet dysfunction. Thromb Res. 1999;94;395-400.

20. Yoshida WB. Radicais livres na síndrome da isquemia e reperfusão. Cir Vasc Angiol. 1996;12;82-95.

21. Granger DN. Role of xanthine oxidase and granulocytes in ischemia-reperfusion injury. Am J Physiol. 1988;255:H1269-75.

22. Montalto MC, Hart ML, Jordan JE, Wada K, Stahl GL. Role for complement in mediating intestinal nitric oxide synthase-2 and superoxide dismutase expression. Am J Physiol. 2003;285:G197-206.

23. Ferreira ALA, Matsubara LS. Radicais livres: conceitos doenças relacionadas sistema de defesa e estresse oxidativo. Rev Assoc Med Brasil. 1997;43:61-8.

24. Xia G, Martin AE, Besner GE. Heparin-binding EGF-like growth factor downregulates expression of adhesion molecules and infiltration of inflammatory cells after intestinal ischemia/reperfusion injury. J Pediatr Surg. 2003;38:434-9.

25. Cerqueira NF, Yoshida WB. Óxido nítrico: revisão. Acta Cir Bras. [serial online] v.17 2002. Disponível em URL: http://www.scielo.br/acb.

26. Cuzzocrea S, Zingarelli B, Caputi AP. Role of constitutive nitric oxide synthase and peroxynitrite production in a rat model of splanchnic artery occlusion shock. Life Sci. 1998;63:789-99.

27. Chan KL, Zhang XH, Fung PCW, Guo WH, Tam PKH. Role of nitric oxide in intestinal ischaemia-reperfusion injury studied using electron paramagnetic resonance. Br J Surg. 1999;86:1427-32.

28. Sekhon B, Sekhon C, Khan M, Patel SJ, Singh I, Singh AK. $\mathrm{N}$-Acetyl cysteine protects against injury in a rat model of focal cerebral ischemia. Brain Res. 2003;971:1-8.

29. Naito Y, Takagi T, Uchiyama K, Handa O, Tomatsuri N, Imamoto E, Kokura S, Ichikawa H, Yoshida N, Yoshikawa T. Suppression of intestinal ischemia-reperfusion injury by a specific peroxisome proliferator-activated receptor-gamma ligand pioglitazone in rats. Redox Rep. 2002;7:294-99.

30. Attuwaybi BO, Kozar RA, Moore-Olufemi SD, Sato N, Hassoun HT, Weisbrodt NW, Moore FA. Heme oxygenase- 1 induction by hemin protects against gut ischemia/reperfusion injury. J Surg Res. 2004;118:53-7.

31. Zou L, Attuwaybi B, Kone BC. Effects of NF-kappa B inhibition on mesenteric ischemia-reperfusion injury. Am J Physiol. 2003;284: G713-21.

32. Zhang M, Austen WGJr, Chiu I, Alicot EM, Hung R, Ma M, Verna N, Xu M, Hechtman HB, Moore FDJr, Carroll MC. Identification of a specific self-reactive IgM antibody that initiates intestinal ischemia/reperfusion injury. Proc Natl Acad Sci USA. 2004;101:3886-91.

33. Fleming SD, Mastellos D, Karpel-Massler G, SheaDonohue T, Lambris JD, Tsokos GC. C5a causes limited polymorphonuclear cell-independent mesenteric ischemia/reperfusion-induced injury. Clin Immunol. 2003;108:263-73. Disponível em: www.sciencedirect.com. Acesso em: 15 ago 2004.

34. Massberg S, Enders G Leiderer R, Eisenmenger S, Vestweber D, Krombach F, Messmer K. Platelet-endothelial cell interactions during ischemia/reperfusion: the role of Pselectin. Blood. 1998;15:507-15.

35. Cooper D, Chitman KD, Williams MC, Granger DN. Timedependent platelet-vessel wall interactions induced by intestinal ischemia-reperfusion. Am J Physiol Gastrointest Liver Physiol. 2003;284:1027-33.

36. Teramoto Y, Urano T, Nagai N, Takada Y, Ikeda K, Takada A. Plasma levels of 5-HT and 5-HIAA increased after intestinal ischemia/reperfusion in rats. Jpn J Physiol. 1998;48:333-9.

37. Rosario HS, Waldo SW, Becker SA, Schmid-Schonbein GW. Pancreatic trypsin increases matrix 
metalloproteinase- 9 accumulation and activation during acute intestinal ischemia-reperfusion in the rat. Am J Pathol. 2004;164:1707-16.

38. Wu B, Iwakiri R, Ootani A, Fujise T, Tsunada S, Fujimoto K. Platelet-activating factor promotes mucosal apoptosis via FasL-mediating caspase-9 active pathway in rat small intestine after ischemia-reperfusion. FASEB J. 2003;17:1156-8.

39. Kuenzler KA, Pearson PY, Schwartz MZ. IL-11 pretreatment reduces cell death after intestinal ischemiareperfusion. J Surg Res. 2002;108:268-72.

40. Noda T, Iwakiri R, Fujimoto K, Matsuo S, Aw TY. Programmed cell death induced by ischemia-reperfusion in rat intestinal mucosa. Am J Physiol. 1998;274:G270-6.

41. Jacob T, Ascher E, Hingorani A, Kallakuri S. Glycine prevents the induction of apoptosis attributed to mesenteric ischemia/reperfusion injury in a rat model. Surgery. 2003;134;457-66.

42. Wu B, Iwakiri R, Tsunada S, Utsumi H, Kojima M, Fujise T, Ootani A, Fujimoto K. iNOS enhances rat intestinal apoptosis after ischemia-reperfusion. Free Radic Biol Med. 2002;33:649-58.

43. Hung WT, Chen Y, Tseng SH, Li HL, Chen CK. Fetal bovine serum suppresses apoptosis in the small intestine after total ischemia and reperfusion in mice. $\mathrm{J}$ Pediatr Surg. 2004;39:1077-83.

44. Horie Y, Yamagishi Y, Kato S, Kajihara M, Kimura H, Ishii H. Low-dose ethanol attenuates gut ischemia/ reperfusion-induced liver injury in rats via nitric oxide production. J Gastroenterol Hepatol. 2003;18:211-7.

45. Horton JW, White DJ. Lipid peroxidation contributes to cardiac deficits after ischemia and reperfusion of the small bowel. Am J Physiol. 1993;264:H1686-92.

46. Rothenbach P, Turnage RH, Iglesias J, Riva A, Bartula L, Myers SI. Downstream effects of splanchnic ischemiareperfusion injury on renal function and eicosanoid release. J Appl Physiol. 1997;83:530-6.

47. Vinardi S, Pierro A, Parkinson EJ, Vejchapipat P, Stefanutti G, Spitz L, Eaton S. Hypothermia throughout intestinal ischaemia-reperfusion injury attenuates lung neutrophil infiltration. J Pediatr Surg. 2003;38:88-91.

48. Khanna A, Rossman JE, Fung HL, Caty MG. Intestinal and hemodynamic impairment following mesenteric ischemia/reperfusion. J Surg Res. 2001;99:114-9.

49. Iglesias JL, Lanoue JL, Rogers TE, Inman L, Turnage RH. Physiologic basis of pulmonary edema during intestinal reperfusion. J Surg Res. 1998;80:156-63.

50. Ciz M, Cizova H, Lojek A, Kubala L, Papezikova I. Ischemia/reperfusion injury of rat small intestine: the effect of allopurinol dosage. Transplant Proc. 2001;33:2871-3.

51. Ilhan H, Alatas O, Tokar B, Colak O, Pasaoglu O, Koku N. Effects of the anti-ICAM-1 monoclonal antibody allopurinol and methylene blue on intestinal reperfusion injury. J Pediatr Surg. 2003;38:1591-5.

52. Alves GES, Matos JJRT, Faleiros RR, Santos RL, Marques Júnior AP. Effect of hydrocortisone on reperfusion injury and on mucosal repair after experimental venous ischemia in the equine jejunum. Arq Bras Med Vet Zootec. [serial online] v.55 2003. Disponível em: http://www.scielo.br/scielo. Acesso em: 15 ago 2004.
53. Vatistas NJ, Snyder JR, Hildebrand SV, Harmon FA, Woliner MJ, Barry SJ, Nieto J, Henry P, Enos LR, Magliano D, Brown SA, Drake C. Effects of U-74389G a novel 21-aminosteroid on small intestinal ischemia and reperfusion injury in horses. Am J Vet Res. 1996;57:762-70.

54. Abrahão MS, Montero EFS, Junqueira VBC, Giavarotti L, Juliano Y, Fagundes DJ. Biochemical and morphological evaluation of ischemia-reperfusion injury in rat small bowel modulated by ischemic preconditioning. Transplant Proc. 2004;36;860-2.

55. Sileri P, Sica G, Gentileschi P, Venza M, Manzelli A, Palmieri G, Spagnoli LG, Testa G, Benedetti E, Gaspari AL. Ischemic preconditioning protects intestine from prolonged ischemia. Transplant Proc. 2004;36:283-5.

56. Hassoun HT, Fischer UM, Attuwaybi BO, Moore FA, Safi HJ, Allen SJ, Cox CSJr. Regional hypothermia reduces mucosal NF-kappa B and PMN priming via gut lymph during canine mesenteric ischemia/reperfusion. J Surg Res. 2003;115;121-6.

57. Attuwaybi BO, Hassoun HT, Zou L ,Kozar RA, Kone BC, Weisbrodt NW, Moore FA. Hypothermia protects against gut ischemia/reperfusion-induced impaired intestinal transit by inducing heme oxygenase-1. J Surg Res. 2003;115:48-55.

58. Aldemir M, Ozturk H, Guloglu C, Buyukbayram H. Effects of in vivo freezing and mannitol in intestinal ischaemiareperfusion injury. Injury. 2003;34:173-9. Disponível em: www.elsevier.com/locate/injury. Acesso em: 15 ago 2004.

59. Steeb GD, Wilson MA, Garrison N. Pentoxifylline preserves small-intestine microvascular blood flow during bacteremia. Surgery. 1992;112:756-64.

60. Byrka-Owczarek K, Steplewska-Mazur K, Krason M, Bohosiewicz J, Koszutski T, Wojtynek G. The evaluation of the protective action of antioxidants on small intestine of rabbits experimentally injured by ischemia and reperfusion. J Pediatr Surg. 2004;39:1226-9.

61. Kozar RA, Holcomb JB, Hassoun HT, Macaitis J, Desoignie R, Moore FA. Superior mesenteric artery occlusion models shock-induced gut ischemiareperfusion. J Surg Res. 2004;116:145-50.

62. Iwanami K, Takeyoshi I, Ohwada S, Kobayashi J, Kawashima Y, Ogawa T, Hasegawa Y, Kawata K, Aiba M, Matsumoto K, Morishita Y. Comparative study of intramucosal $\mathrm{pH}$ in histologic damage from small bowel ischemia-reperfusion injury. Transplant Proc. 1998;30;3467-8.

63. Gutteridge JMC, Halliwell B. The measurement and mechanism of lipid peroxidation in biological systems. Tibs. 1990;15:129-35.

64. Holley AE, Cheeseman KH. Mensuração das reações dos radicais livres in vivo. In: Cheeseman KH, Slater TF. Radicais livres em medicina. Rio de Janeiro: Interlivros; 1996. p.15-25.

65. Hegde SS, Seidel SA, Ladipo JK, Bradshaw LA, HALTER $\mathrm{S}$, Richards WO. Effects of mesenteric ischemia and reperfusion on small bowel electrical activity. J Surg Res. 1998;74:86-95.

66. Sun XQ, Fu XB, Zhang R, Lu Y, Deng Q, Jiang XG, Sheng ZY. Relationship between plasma D(-)-lactate and intestinal damage after severe injuries in rats. World J Gastroenterol. 2001;7:555-8. 
67. Günel E, Caglayan O, Caglayan F. Serum D-lactate levels as a predictor of intestinal ischemia-reperfusion injury. Pediatr Surg Int. 1998;14:59-61.
68. Niewold TA, Meinen M, Van der Meulen J. Plasma intestinal fatty acid binding protein (I-FABP) concentrations increase following intestinal ischemia in pigs. Res Vet Sci. 2004;77:89-91.

\section{Correspondence:}

Nereide Freire Cerqueira

Departamento de Cirurgia e Anestesiologia Veterinária

Faculdade de Medicina Veterinária e Zootecnia de Botucatu - UNESP

Distrito de Rubião Jr. - Caixa Postal 560

CEP: 18618-000 - Botucatu - SP - Brazil

Telephone: 551438116252

Fax: 551438116072

e-mail: nereide@fmvz.unesp.br
Conflict of interest: none Financial source: FAPESP

Received: March 21, 2005

Revised: April 25, 2005

Aproved: May 23, 2005

\title{
Como citar este artigo:
}

Cerqueira NF, Hussni CA, Yoshida WB. Pathophysiology of mesenteric ischemia/reperfusion: a review. Acta Cir Bras. [serial online] 2005 Jul-Aug;20(4). Disponível em URL: http://www.scielo.br/acb

\section{Elaboração e Apresentação de Comunicação Científica}

\author{
Saul Goldenberg
}

Carlos Alberto Guimarães

Aldemar Araujo Castro

Editores

Consulte: http://www.metodologia.org 